\title{
A SEMIOTIC ANALYSIS OF SUMPAH POCONG AMONG MADURANESE PEOPLE: A CASE STUDY OF POLAGAN DISTRICT, SAMPANG-MADURA
}

Semiotika Sumpah Pocong pada Masyarakat Madura: Studi Kasus Kelurahan Polagan, Sampang-Madura

\section{Mukarromah}

Fakultas Ilmu Budaya, Universitas Airlangga

Email: mukarromah-2020@fib.unair.ac.id

\begin{abstract}
Sumpah pocong is a tradition that is still performed by the Madurese community, especially in the Polagan Village, Madegan, Sampang. This study aims to seek the meaning contained in sumpah pocong based on the signs in sumpah pocong also the concept of signifier and signified by Ferdinand de Saussure. The method used in this research is descriptive qualitative by utilizing field studies through interviews and direct documentation in Polagan Village. The results of this study indicate that the community has different opinions and views in interpreting sumpah pocong.
\end{abstract}

Keywords: Sumpah pocong, Semiotics, Signifier, Signified

\begin{abstract}
Abstrak: Sumpah pocong merupakan sebuah tradisi yang masih dilakukan oleh masyarakat Madura, khususnya di Kelurahan Polagan, Dusun Madegan Kec. Sampang Kab. Sampang. Penelitian ini bertujuan untuk melihat makna yang terkandung dalam sumpah pocong berdasarkan tanda-tanda yang terdapat dalam ritual sumpah pocong berdasarkan pada konsep signifier (penanda) dan signified (petanda) Ferdinand de Saussure. Metode yang digunakan dalam penelitian ini adalah kualitatif deskriptif dengan memanfaatkan studi lapangan serta wawancara dan dokumentasi secara langsung di Kelurahan Polagan. Hasil dari penelitian ini diperoleh bahwa masyarakat memiliki perbedaan pendapat dan pandangan masing-masing dalam memaknai sumpah pocong.
\end{abstract}

Kata kunci: Sumpah pocong, Semiologi, Penanda, Petanda

\section{PENDAHULUAN}

Indonesia merupakan negara yang terdiri dari berbagai macam suku bangsa, ras, dan etnis dengan berbagai tradisi dan budaya yang dimiliki oleh masing-masing daerah. Salah satunya adalah budaya atau tradisi yang terdapat di Madura, yaitu sumpah pocong. Sumpah pocong bukanlah suatu tradisi baru yang dilakukan oleh masyarakat Madura, namun telah dilakukan sejak dari jaman dahulu oleh para leluhur. Menurut Nopiyanti (2020), hampir tidak ada satu pun kajian pustaka yang membahas khusus mengenai sumpah pocong. Tetapi menurut orang-orang tua, sumpah ini sudah ada sejak jaman dahulu sekali dan telah menjadi ritual yang kerap dilakukan.

Sumpah pocong kerap kali dilakukan di salah satu daerah di Madura yang terletak di Kelurahan Polagan, Dusun Madegan, Kecamatan Sampang. Tempat ini dikenal sebagai pusat sumpah pocong di Madura. Hal ini diyakini oleh masyarakat Kelurahan Polagan bahwa tempat ini merupakan tempat 
dilaksanakannya sumpah pocong untuk pertama kali serta keterkaitannya dengan Masjid Madegan. Masjid ini merupakan masjid tertua di Madura dan diyakini memiliki kekuatan gaib. Maka tidak heran masjid ini digunakan sebagai tempat berlangsungnya pelaksanaan sumpah, karena masjid ini dipercaya mampu memberikan keampuhan bagi sumpah yang diucapkan.

Sumpah pocong umumnya dilakukan ketika dua orang atau lebih memiliki suatu permasalahan, namun keduanya tidak lagi dapat menyelesaikan masalah secara hukum maupun kekeluargaan. Sehingga sumpah pocong dipilih sebagai cara untuk menyelesaikan masalah mereka. Sebagaimana yang kita tahu bahwa sebagai makhluk sosial manusia tidak akan lepas dari interaksi satu sama lain, sehingga kadang kala terjadilah suatu konflik antar perorangan maupun antar masyarakat lainnya. Menurut Kinasih (2013), umumnya upaya yang dilakukan untuk menyelesaikan suatu konflik tersebut adalah dengan menyelesaikan secara hukum, tetapi berbeda halnya bagi sebagian orang yang menganggap bahwa hukum tidak bisa lagi dijadikan sebagai cara untuk menyelesaikan masalah. Biasanya permasalahan muncul karena adanya konflik antara seorang sebagai penggugat melawan orang lain sebagai tergugat. Masing-masing pihak yang bersengketa kekurangan bukti-bukti dan saksi-saksi yang kuat sehingga tidak mungkin untuk diselesaikan ke jalur pengadilan.

Umumnya orang yang melakukan sumpah percaya bahwa hukum Allah lebih nyata sehingga sampai saat ini, tidak jarang sumpah pocong masih menjadi pilihan bagi sebagian orang untuk menyelesaikan masalahnya. Hal ini dibuktikan dari beberapa ritual yang telah dilakukan pada beberapa bulan yang lalu. Ritual ini dilakukan oleh dua warga Kabupaten Pamekasan-Madura atas tuduhan santet. Menurut salah satu warga Madegan, ritual tersebut dilaksanakan pada tanggal 12 September 2020 yang bertempat di Masjid Madegan, SampangMadura.

Pelaksanaan sumpah pocong dimulai dengan berwudhu. penggugat dan tertuduh diminta untuk berwudhu terlebih dahulu untuk menyucikan diri mereka. Setelah itu pelaksanaannya dimulai dari pihak penggugat untuk dikafani dan berbaring menghadap kiblat. Tubuhnya dibungkus dengan kain kafan seperti orang meninggal kecuali hanya wajahnya saja. Ritual ini dilakukan di dalam Masjid Madegan, tepatnya di tengah-tengah empat tiang masjid yang diyakini memiliki kekuatan magic. Setelah dikafani, kemudian diletakkan sebuah AlQuran di atas mereka dan dilanjutkan dengan pembacaan sumpah yang dipimpin oleh takmir masjid dan harus diikuti oleh penggugat yang dimulai dengan bacaan Basmalah dan membaca kedua syahadat.

Hal tersebut dilakukan secara bergantian. Setelah masing-masing mengucapkan sumpah, mereka kemudian diberi air dan tongkat dicelup ke dalam air tersebut. Setelah itu, telah disiapkan dua ekor ayam putih untuk disembelih. Setelah ayam itu mati, maka keduanya diharuskan melangkahi ayam tersebut secara bergantian sebanyak 7 kali. Selanjutnya keduanya diwajibkan untuk mengelilingi sebuah pohon sawo yang masih berada di dalam masjid juga sebanyak 7 kali. Setelah tata cara di atas telah dilakukan maka pelaksanaan sumpah pocong telah selesai.

Sumpah pocong sebagai tradisi yang telah lama dilakukan masih menjadi topik menarik. Hal ini dibuktikan dari beberapa penelitian mengenai sumpah 
pocong di Madura. Salah satunya adalah penelitian yang dilakukan oleh Anwar (2008) berjudul Konsep Mubahalah dan Praktik Sumpah Pocong di Kabupaten Sumenep. Disimpulkan bahwa mubahalah adalah berdoa kepada Allah SWT untuk memberikan laknat bagi pihak lawan sebagai media untuk menguji keberanian dan menunjukkan siapa yang benar di antara keduanya. Sumpah pocong di kabupaten Sumenep-Madura adalah relevan dengan peristiwa mubahalah pada masa Nabi Muhammad SAW. Keduanya sama-sama masuk dalam kategori tagliz al-yamin, hanya saja mubahalah dikuatkan dengan cara mengajak keluarga terdekat sedangkan sumpah pocong dengan dikafani sebagaimana orang meninggal. Maka dengan ini, peneliti tertarik untuk meneliti tanda-tanda yang terdapat dalam ritual sumpah pocong untuk melihat makna yang terkandung dalam sumpah pocong.

Ferdinand de Saussure (1857-1913) dan Charles Sanders Peirce (18391914) merupakan dua tokoh semiotika modern yang sangat berpengaruh dalam linguistik dan semiotik. Keduanya sama-sama memiliki konsep seperti tanda dan penanda, signifier dan signified oleh Saussure, sedangkan Pierce dengan konsep sign, object, dan interpretant (Syafieh \& Nurbaiti, 2018). Namun dalam penelitian ini, peneliti akan memfokuskan pada aplikasi teori Ferdinand de Saussure. Bagi Saussure (1996), semiotika adalah kajian mengenai tanda dalam kehidupan sosial, mencakup apa saja tanda tersebut dan hukum apa yang mengatur terbentuknya tanda. Konsep dasar semiotik terdapat pada sistem dikotomi tanda, yaitu penanda dan petanda. Hal ini seperti yang dikatakan oleh Saussure bahwa tanda merupakan suatu kesatuan dari penanda dan petanda. Petanda adalah bunyi yang memiliki makna, sedangkan petanda adalah aspek material dari bahasa. Petanda tidak akan ada artinya tanpa penanda, karena itu bukan sebuah tanda. Hubungan antara penanda maupun petanda saling memiliki ketergantungan satu sama lain. Selanjutnya, teori Ferdinand de Saussure dipilih berdasarkan konsep penanda dan petanda sebagai analisis objek dalam penelitian ini adalah semiotika sumpah pocong pada masyarakat Madura.

Semiotika merupakan ilmu yang mempelajari tentang tanda (sign), fungsi tanda, dan produksi makna. Tanda adalah sesuatu yang bagi seseorang berarti sesuatu yang lain. Sesuatu yang dapat diamati ataupun dibuat teramati dapat disebut tanda. Sehingga, tanda tidak terbatas pada benda dan bahasa. Adanya peristiwa maupun tidak adanya peristiwa, struktur yang ditemukan serta suatu kebiasaan, hal tersebut dapat disebut sebagai tanda. Suatu tanda menandakan sesuatu selain dirinya sendiri dan makna adalah hubungan antara suatu objek atau ide dan suatu tanda (Halid, 2019).

Dalam pandangan Saussure, bahasa adalah suatu sistem tanda, yang mana setiap tanda terdiri dari dua bagian yaitu penanda (signifier) dan petanda (signified). Hal tersebut merupakan inti pokok pada teori Saussure. Saussure beranggapan bahwa setiap tingkah laku manusia membawa makna yang berfungsi sebagai tanda, sehingga terdapat sistem perbedaan dan konvensi yang memungkinkan makna tersebut di belakangnya. Saussure dalam mempelajari tanda-tanda dalam masyarakat yaitu mempelajari dari mana dan dari apa saja tanda-tanda atau kaidah-kaidah yang mengaturnya (Halid, 2019).

Saussure menggunakan istilah semiologi. Konsep Semiotika atau semiologi Ferdinand de Saussure adalah signifier dan signified. Dua hal tersebut 
merupakan hal yang cukup penting dalam menangkap hal pokok mengenai teori Saussure yang mengatakan bahwa bahasa itu adalah suatu sistem tanda, yang mana setiap tanda tersusun dari dua bagian, yaitu signifier (penanda) dan signified (petanda). Menurut Saussure, bahasa tersusun atas sistem tanda yang mengandung makna. Sebagaimana semiotika adalah ilmu yang mempelajari tentang tanda (sign), fungsi tanda, dan produksi makna. Tanda adalah sesuatu yang bagi seseorang berarti sesuatu yang lain. Sesuatu yang dapat diamati atau dibuat teramati dapat disebut tanda. Karena itu tanda tidaklah terbatas pada benda dan bahasa (Halid, 2019).

\section{METODE PENELITIAN}

Penelitian ini menggunakan penelitian jenis kualitatif. Kualitatif adalah metode yang menjadikan seorang peneliti memegang peran penting (Danial, 2009; Poerwandari \& Kristi, 2005). Dengan metode kualitatif, peneliti dapat memahami dan memaknai suatu fenomena sosial berdasarkan perspektif diri peneliti sendiri (Usman \& Setiady, 2017, p. 121). Penelitian kualitatif juga digunakan dalam usaha untuk memahami dinamika kebudayaan (Koentjaraningrat, 1997). Penggunaan metode penelitian kualitatif sebagai usaha untuk memahami dinamika kebudayaan secara deskriptif (Koentjaraningrat, 1997; Lexy \& Moleong, 2007). Dalam penelitian ini, fenomena kebudayaan sumpah pocong.

Peneliti melakukan penelitian yang berlokasi di kelurahan Polagan, dusun Madegan, Kecamatan Sampang-Madura. Tempat ini dikenal dengan sumpah pocongnya dan dianggap sebagai pusat ritual sumpah pocong di Madura. Tepatnya di Masjid Madegan yang digunakan sebagai tempat pelaksanaan sumpah pocong. Masjid Madegan menjadi masjid tertua dan menyimpan beberapa benda yang dibutuhkan dalam pelaksanaan sumpah pocong. Penulis melakukan penelitian pada hari Sabtu, 17 Oktober 2020.

Teknik penentuan informan peneliti menggunakan teknik purposive sampling, yaitu teknik pengambilan sampel yang didasarkan atas tujuan tertentu (orang yang dipilih betul-betul memiliki kriteria sebagai sampel) (Sugiyono, 2013, p. 85). Informan ini dibutuhkan untuk mengetahui mengenai hal yang berkaitan dengan sumpah pocong di kelurahan Polagan, Dusun Madegan, Kec. Sampang Kab. Sampang.

Pemilihan informan dalam penelitian ini didasarkan pada orang-orang yang dianggap mampu untuk memberikan informasi secara lengkap yang berkaitan dengan penelitian sehingga data yang diperoleh dapat diakui kebenarannya. Dalam penelitian terdapat tiga informan yaitu Juru Pelihara Makam Madegan, seorang guru di salah satu sekolah di Madegan, dan seorang warga setempat.

Kriteria yang menjadi tolak ukur, yaitu:

a. Juru pelihara Makam Madegan (selanjutnya disebut Informan 1)

1. Pemelihara makam di sebelah Masjid Madegan sebagai tempat sumpah pocong

2. Masyarakat Madegan

3. Pernah mengikuti kegiatan sumpah pocong yang dilakukan di Masjid Madegan 
4. Bersedia menjadi informan

5. Dapat diajak komunikasi dan dimintai pendapat

b. Guru (informan 2)

1. Masyarakat Madegan

2. Pernah mengikuti kegiatan sumpah pocong yang dilakukan di Masjid Madegan

3. Bersedia menjadi Informan

4. Dapat diajak komunikasi dan dimintai pendapat

c. Warga setempat (Informan 3)

1. Masyarakat Madegan

2. Pernah mengikuti kegiatan sumpah pocong yang dilakukan di Masjid Madegan

3. Bersedia menjadi Informan

4. Dapat diajak komunikasi dan dimintai pendapat

Proses pengumpulan data pada penelitian ini menggunakan teknik dokumentasi dan wawancara. Dokumentasi yang dilakukan oleh peneliti adalah memotret tanda-tanda yang digunakan dalam tata cara pelaksanaan sumpah pocong seperti Masjid, kain kafan, ayam putih, pohon sawo, dan tongkat. Selanjutnya peneliti melakukan wawancara dengan ketiga informan. Saat melakukan wawancara peneliti menggunakan teknik rekam dan catat. Selain dokumentasi dan wawancara, peneliti juga menggunakan studi pustaka untuk menunjang data-data yang dibutuhkan dalam penelitian.

Peneliti menggunakan teknik analisis deskriptif yang dilakukan secara kualitatif dan menggunakan teori semiotika dari Ferdinand de Saussure dengan konsep signifier (penanda) dan signified (petanda). Analisis data dilakukan dengan memutar kembali rekaman hasil wawancara dan mencatat hal-hal penting yang berkaitan dengan objek permasalahan dalam penelitian ini. Mencatat tanda-tanda apa saja yang terdapat dalam pelaksanaan sumpah pocong, menganalisis tanda-tanda yang ditemukan, dan dihubungkan dengan konsep semiotika Ferdinand de Saussure, serta langkah terakhir yaitu menarik kesimpulan.

\section{HASIL DAN PEMBAHASAN}

Sumpah pocong adalah suatu tradisi sumpah dengan membalutkan kain kafan seperti orang meninggal dan beberapa macam proses lainnya. Sumpah pocong sebagai tradisi atau budaya masih sangat dipercaya oleh masyarakat dalam menyelesaikan suatu permasalahan. Sumpah pocong dilakukan di sebuah masjid, yaitu Masjid Madegan dengan proses dan tata cara yang harus dilakukan oleh kedua belah pihak yang akan bersumpah.

Penelitian ini dianalisis menggunakan teori semiotika/ semiologi Ferdinand de Saussure dengan konsep signifier (penanda) dan signified (petanda). Yaitu mencari penanda dan petanda yang terdapat dalam pelaksanaan sumpah pocong. Dengan demikian, diperoleh tanda-tanda yang terdapat dalam pelaksanaan sumpah pocong antara lain: (1) Sumpah atas nama Allah, (2) Pembacaan kalimat syahadat, (3) berwudhu, (4) Masjid, (5) kain kafan, (6) ayam putih polos, (7) pohon sawo, dan (8) tongkat. 
Bersumpah Atas Nama Allah SWT

\begin{tabular}{|l|l|}
\hline $\begin{array}{l}\text { Signifier } \\
\text { (penanda) }\end{array}$ & Signified (petanda) \\
\hline $\begin{array}{l}\text { Bersumpah atas } \\
\text { nama Allah SWT }\end{array}$ & $\begin{array}{l}\text { Petanda bahwa manusia menegaskan pernyataan yang } \\
\text { diucapkan dengan bersaksi kepada Allah SWT. }\end{array}$ \\
\hline
\end{tabular}

Berdasarkan uraian tabel di atas, memberikan kesan makna bahwa dalam sumpah pocong, kedua belah pihak yang disumpah bersaksi kepada Allah semata untuk menguatkan kebenaran dan kesungguhan. Yang mana antara keduanya ingin menegaskan bahwa dirinya benar dalam perkataannya atau berusaha untuk membersihkan diri dari tuduhan yang ditujukan kepadanya, sehingga bersumpahlah mereka dengan menyebut nama Allah SWT.

Istilah sumpah dapat diartikan suatu perjanjian yang diteguhkan dengan memakai nama Allah. Sumpah merupakan suatu pernyataan ketersediaan dan kesanggupan yang datang dari kehendak dan hati nurani seseorang untuk melakukan atau tidak melakukan sesuatu dengan menyebut nama Allah. Sehingga tercipta suatu perjanjian lahir dan batin antara pengikrar sumpah mengikat dengan Tuhan Allah, dan kesanggupan itu tidak terbatas pada atasan atau orang yang meyakinkan serta meminanya saja melainkan lebih mengikat terhadap Allah SWT. Karena sumpah itu bagaikan mempertahankan nama-Nya sebagai jaminan (Hidayanto, 1993, p. 54).

Adapun terdapat beberapa macam sumpah. Pertama, sumpah sia-sia atau main-main yaitu sumpah yang tidak menanggung konsekuensi hukum (Hidayanto, 1993, p. 54). Kedua, sumpah sungguh-sungguh yaitu sumpah yang dikuatkan dengan niat dan maksud. Sumpah ini termasuk sumpah yang sah karena menggunakan huruf Qasam, yaitu: Wallahi, Billahi dan Tallahi yang artinya "Demi Allah" kemudian diiringi dengan isi sumpah. Ketiga, Sumpah palsu yaitu mengelabui orang lain dengan sumpah dusta.

Menurut Informan 2 yang mengatakan bahwa sumpah atas nama Allah merupakan sumpah dengan kedudukan tertinggi, tidak ada sumpah melebihi sumpah atas nama Allah yang tentunya bukanlah sumpah yang bisa dianggap main-main. Sebagaimana dalam sumpah pocong, sebagai seorang muslim, mereka disumpah atas nama Allah dengan harapan mereka tidak bermain-main dengan sumpah dan memikirkan resiko yang akan diterima jika terbukti bersalah namun tetap melaksanakan sumpah.

\section{Membaca Kalimat Syahadat}

\begin{tabular}{|l|l|}
\hline $\begin{array}{l}\text { Signifier } \\
\text { (penanda) }\end{array}$ & Signified (petanda) \\
\hline $\begin{array}{l}\text { Pembacaan kalimat } \\
\text { syahadat }\end{array}$ & $\begin{array}{l}\text { Petanda bahwa dalam ritual sumpah pocong mereka } \\
\text { disumpah untuk bersaksi bahwa tidak ada Tuhan selain } \\
\text { Allah dan Nabi Muhammad adalah utusan Allah. }\end{array}$ \\
\hline
\end{tabular}

Berdasarkan tabel di atas memberikan kesan makna sebuah pernyataan yang memiliki arti bersaksi. Dua kalimat syahadat merupakan rukun pokok terpenting dalam Islam karena syahadat merupakan pondasi, esensi, dan sumber kekuatan utama dan di atasnya lah seluruh bangunan ketetapan dan kewajiban 
syariat berdiri dan ditegakkan (Wayadi, 2009). Akan tetapi kalimat tersebut juga mengandung makna yang sangat dalam yaitu mempersaksikan dan memastikan dan konsekuensinya adalah mempertaruhkan hidup demi kebenaran dan kepastian yang telah diyakini dalam syahadat tersebut.

Syahadatain adalah dua kalimat syahadat karena kalimat tersebut mengandung dua syahadat (penyaksian). Syahadat pertama yaitu La ilaha illa allah yang berarti tidak ada Tuhan selain Allah SWT. Kalimat tersebut bermakna bahwa Tidak ada tuhan yang patut disembah selain Allah SWT dan syahadat kedua adalah Muhammad Rasulullah yang berarti Muhammad adalah utusan Allah.

Berwudhu

\begin{tabular}{|l|l|}
\hline $\begin{array}{l}\text { Signifier } \\
\text { (penanda) }\end{array}$ & Signified (petanda) \\
\hline Berwudhu & $\begin{array}{l}\text { Petanda bahwa mereka yang melakukan sumpah } \\
\text { dianjurkan untuk menyucikan diri dengan berwudhu } \\
\text { sebagaimana para umat Islam berwudhu sebelum } \\
\text { melakukan ibadah sholat. }\end{array}$ \\
\hline
\end{tabular}

Berdasarkan tabel di atas, memberikan kesan makna kesucian diri. Dalam Islam perintah melaksanakan wudhu bersamaan dengan perintah mengerjakan sholat. Berwudhu yaitu menggunakan air pada bagian tubuh tertentu yang bertujuan untuk membersihkan dan menyucikan. Dalam pelaksanaan sumpah pocong, kedua belah pihak diwajibkan untuk berwudhu dengan maksud menyucikan diri mereka sebelum mengucap sumpah. Hal ini juga menunjukkan bahwa Islam merupakan agama yang suci dan bersih, yang mana Islam membawa ajaran kesucian dan kebersihan.

Suci bersih di sini berarti suci dalam segala hal, baik dari segi fisik, akhlak, pikiran dan sebagainya. Sebagaimana dalam hal fisik, Islam mengajarkan penganutnya agar bersih pakaian dan tempat (Jamal, 2011, p. 288). Seperti halnya sebelum sholat, wajib bagi seorang muslim untuk bersuci dan berwudhu. Senada dengan Riyanto yang menyatakan bahwa kebersihan rohani dan fisik wajib dijaga sebelum melakukan sholat (2003, p. 101).

"the cleanliness of the place where the shalat is performed, the person's own cleanliness is also an obligatory, both physical and spiritual. The most popular way of purifying oneself before performing shalat is by doing wudlu or ablution" (Riyanto, 2003, p. 101).

Dalam kata lain kebersihan/kesucian meliputi banyak hal, tidak hanya dari segi tempat, namun jasmani dan juga kebersihan rohani yaitu dengan cara berwudhu yang biasanya dilakukan sebelum melaksanakan sholat. Sama halnya, sebelum seseorang disumpah maka ia diwajibkan untuk berwudhu dengan tujuan terhindar dari kotoran dan bersih baik secara jasmani dan rohaninya.

Sebagaimana dijelaskan oleh Riyanto (2003, p. 101), dalam pelaksanaan wudhu seseorang diwajibkan untuk membasuh beberapa bagian tubuh dari ujung kepala sampai kaki. Seperti halnya membasuh kedua telapak tangan, 
membasuh wajah, membasuh tangan sampai siku, membasuh kepala, dan membasuh kaki hingga mata kaki.

"In doing an ablution a Muslim will wash some parts of his or her body using water as required in the regulation. Among them are the hands, the face, the forehead and the foot" (Riyanto, 2003, p. 101).

Bersuci atau dalam istilah Islam disebut "Thaharah" yang memiliki makna yang luas dan tidak hanya sebatas berwudhu saja. Thaharah adalah menyucikan diri, pakaian, dan tempat sholat dari hadas dan najis menurut syariat Islam. Bersuci merupakan syarat sah seorang muslim untuk melaksanakan ibadah tertentu (Subandi, 2007).

\section{Masjid Madegan}

\begin{tabular}{|l|l|}
\hline $\begin{array}{l}\text { Signifier } \\
\text { (penanda) }\end{array}$ & Signified (petanda) \\
\hline Masjid Madegan & $\begin{array}{l}\text { Petanda sebagai tempat yang suci dan disakralkan. } \\
\text { Pelaksanaan sumpah pocong selalu di masjid karena akan } \\
\text { menambah keyakinan bagi orang yang disumpah dan } \\
\text { memiliki keampuhan sumpah tersebut. }\end{array}$ \\
\hline
\end{tabular}

Berdasarkan tabel di atas, memberikan kesan makna bahwa Masjid Madegan sebagai tempat berlangsungnya sumpah pocong karena masjid sebagai rumah Allah SWT diyakini akan menambah kesakralan dari sumpah pocong juga akan menambah keyakinan bagi orang yang disumpah. Sehingga orang-orang tidak akan main-main dengan sumpah mereka. Sumpah pocong tidak lepas dari sebuah tempat suci dan sakral yaitu Masjid Madegan. Masjid Madegan atau dikenal juga dengan masjid Tiban merupakan masjid tertua di Sampang. Di samping itu, pada jaman dahulu, Masjid Madegan sangat erat dengan kekuatan magis sehingga dipercaya sebagai tempat yang sangat suci dan sakral. Oleh karena itu, Masjid Madegan juga digunakan sebagai tempat berlangsungnya ritual sumpah pocong. Berdasarkan Intisari (1996), pelaksanaan sumpah pocong selalu di masjid karena akan menambah keyakinan bagi orang yang disumpah dan memiliki keampuhan sumpah pocong tersebut.

Masjid merupakan kata lain yang diambil dari kata "sujud", bentuk dasarnya adalah sajada-yasjudu. Al-masjid berarti tempat bersujud. Al-Masjad berarti kening orang yang berbekas sujud. Sebagian berpendapat bahwa AlMasjid berarti rumah tempat bersujud, sedangkan Al-Masjad berarti rumahrumah atau tempat sholat di berbagai perkumpulan (Syakirin, 2018, p. 133).

Informan 1 berpendapat bahwa masjid sebagai tempat seorang muslim melaksanakan sholat. Pada dasarnya setiap muslim dapat melaksanakan sholat dimanapun tidak hanya di masjid. Sebagaimana menurut Riyanto (2003, p. 99) yang menyatakan bahwa ketika waktu sholat telah tiba, seorang muslim dapat melaksanakan sholat dimanapun mereka mau, baik di kantor, pasar, di kapal, maupun di kereta api. Meski ada baiknya seorang muslim mencari masjid untuk sholat, namun ketika mereka tidak dapat menemukan masjid, mereka dapat melaksanakannya dimanapun mereka mau. Pada dasarnya secara leksikal, 
masjid mengacu pada tempat ibadah, namun secara umum orang-orang menggunakan kata masjid untuk merujuk pada bangunan yang dibangun untuk beribadah.

Masjid tidak hanya berfungsi sebagai tempat ibadah, melainkan tidak sedikit beberapa kegiatan yang juga dilakukan di masjid. Safri $(1993$, p. 5) berpendapat bahwa bagi umat Islam, masjid merupakan pusat segala kegiatan. Masjid bukan hanya sebagai pusat ibadah khusus seperti sholat dan i'tikaf, tetapi merupakan pusat kebudayaan mu'amalat. Tempat dimana lahirnya kebudayaan Islam yang demikian kaya dan berkah. Senada dengan Shiddiqqi (1987, p. 171), bahwa fungsi masjid selain sebagai tempat ibadah juga berfungsi untuk: (1) mencerdaskan umat dan memberikan orientasi dakwah, (2) fungsi sosial, sebagai tempat penduduk bisa saling jumpa, saling berkenalan satu sama lain dan menjalin persaudaraan, (3) tempat melaksanakan berbagai kegiatan seperti menghafal Al-qur'an, lembaga amal zakat, lembaga solidaritas, bantuan kemanusiaan, lembaga kursus bagi anak muda dalam bidang ilmu pengetahuan, dan lembaga penengah sengketa. Dengan demikian, masjid tidak hanya sebagai tempat ibadah namun juga pengertian dan fungsi masjid mencakup berbagai aspek kehidupan umat Islam. Sehingga masyarakat menggunakan masjid sebagai tempat melaksanakan pusat pembelajaran maupun berbagai kegiatan lainnya seperti halnya pelaksanaan sumpah pocong yang dilaksanakan di Masjid Madegan.

Ayam Putih

\begin{tabular}{|l|l|}
\hline $\begin{array}{l}\text { Signifier } \\
\text { (penanda) }\end{array}$ & Signified (petanda) \\
\hline Ayam Putih & Petanda yang diartikan sebagai perwujudan hal yang suci. \\
\hline
\end{tabular}

Berdasarkan tabel di atas, memberikan makna perwujudan hal yang suci. Sebagaimana menurut Informan 2 yang mengatakan bahwa ketika salah satu dari orang tersebut meninggal, maka diharapkan dalam keadaan yang suci. Namun berbeda halnya dengan pendapat Informan 1 yang mengatakan bahwa sebagian masyarakat juga mempercayai ayam tersebut merupakan tanda bagaimana cara orang itu akan meninggal. Ayam merupakan perumpamaan sebagai manusia. Setelah melaksanakan prosesi sumpah apabila orang tersebut bermain-main dengan sumpahnya maka cara ia meninggal akan seperti ayam yang telah disembelih tersebut.

Ayam putih menjadi salah satu syarat wajib yang harus dipenuhi oleh kedua belah pihak. Namun karena keterbatasan dan kesulitan untuk mendapatkan ayam putih polos maka terkadang diganti dengan ayam biasa. Menurut Informan 1, penggunaan ayam biasa (bukan ayam putih) memungkinkan terjadinya pengurangan akan kesakralan sumpah pocong. Sehingga saat ini, di antara penggugat dan tertuduh, di antara keduanya yang berdusta atas sumpahnya tidak lagi meninggal sebagaimana ayam yang disembelih. Berbeda dengan yang terjadi pada jaman dahulu yang ketika keluar dari masjid salah satu yang berdusta akan langsung meninggal. Setelah itu, ayam akan disembelih dan mereka wajib melangkahi bangkai ayam tersebut sebanyak 7 kali. Pada dasarnya, hal ini juga diyakini menjadi salah satu penyebab 
berbedanya efek yang ditimbulkan setelah melakukan sumpah pada masa sekarang dengan dahulu.

Kain Kafan

\begin{tabular}{|l|l|}
\hline $\begin{array}{l}\text { Signifier } \\
\text { (penanda) }\end{array}$ & Signified (petanda) \\
\hline Kain Kafan & $\begin{array}{l}\text { Petanda bahwa supaya manusia mengingat kematian atau } \\
\text { meninggal. }\end{array}$ \\
\hline
\end{tabular}

Berdasarkan tabel di atas memberikan kesan makna agar manusia mengingat akan kematian, sehingga orang yang melakukan sumpah mengingat mati dan tidak main-main dengan sumpah.

Kafan adalah kain yang digunakan untuk membungkus orang muslim yang sudah meninggal sebelum dikuburkan. Dalam pelaksanaan sumpah pocong, kain kafan merupakan salah satu benda yang juga dipakai dalam prosesi pelaksanaan tersebut dan digunakan untuk membungkus seseorang sebelum ia melakukan sumpah.

\begin{tabular}{|} 
Pohon Sawo \\
\begin{tabular}{|l|l|}
\hline $\begin{array}{l}\text { Signifier } \\
\text { (penanda) }\end{array}$ & Signified (petanda) \\
\hline Pohon Sawo & $\begin{array}{l}\text { Petanda yang menunjukkan upaya mencari kebenaran di } \\
\text { antara kedua belah pihak. }\end{array}$ \\
\hline
\end{tabular}
\end{tabular}

Berdasarkan uraian tabel di atas, memberikan kesan makna sebagai upaya mencari kebenaran. Sehingga yang terbukti bersalah akan mendapatkan hukuman yang setimpal dari Tuhan. Namun pendapat lain dari Informan 3 mengatakan bahwa kelima pohon sawo tersebut selain dapat diartikan sebagai suatu simbol dari rukun Islam yang berjumlah lima juga sebagai peringatan agar selalu mengingat pada ibadah sembahyang lima waktu. Mengelilingi sawo ini dipercaya merupakan sebuah tempat tirakat pertapa yang membangun Masjid Madegan yang sampai saat ini masih dikeramatkan dan disakralkan.

Pohon sawo ini dianggap sangat sakral bagi masyarakat Madegan oleh karenanya orang yang melakukan sumpah harus mengelilingi pohon sawo ini juga sebanyak 7 kali. Diceritakan juga oleh Hosnanijatun dalam Babad Sampang (2004) bahwa pertapa tersebut menanam lima pohon sawo. Pada salah satu pohon sawo tersebut ia gunakan untuk bertapa atau bersemedi.

\section{Tongkat}

\begin{tabular}{|l|l|}
\hline $\begin{array}{l}\text { Signifier } \\
\text { (penanda) }\end{array}$ & Signified (petanda) \\
\hline Tongkat & $\begin{array}{l}\text { Petanda yang menunjukkan kesakralan dari tongkat } \\
\text { tersebut, yang mampu membuat doa meresap ke dalam } \\
\text { tubuh orang yang bersumpah setelah air yang dicelup } \\
\text { tongkat lalu diminum. }\end{array}$ \\
\hline
\end{tabular}


Berdasarkan tabel di atas, hal tersebut memberikan kesan makna akan kesakralan sebuah benda yaitu tongkat. Tongkat yang diyakini akan membuat doa meresap masuk ke dalam tubuh kedua orang yang bersumpah dengan hanya mencelupkan tongkat tersebut ke dalam sebuah air sebelum akhirnya diminum oleh masing-masing dari mereka. Tongkat adalah satu benda yang digunakan pada prosesi sumpah pocong. Tongkat ini dicelupkan ke dalam air yang sudah dicampur dengan bunga 7 rupa yang sudah diberi doa, kemudian diminumkan kepada kedua belah pihak.

Tongkat ini adalah milik santri atau pertapa yang ditinggal di masjid pada saat selesai pembangunan masjid yang hanya dibangun dalam waktu satu malam tersebut. Tongkat ini pula yang dipercaya telah digunakan untuk membangun masjid dalam satu malam, dengan cara mengayun-ayunkan tongkat pada kayu yang berserakan sehingga Ketika diayun-ayunkan, kayu tersebut perlahan-lahan bertumpuk. Sampai saat ini, tongkat tersebut masih ada di dalam Masjid Madegan dan digunakan Ketika dilaksanakannya ritual sumpah pocong.

\section{Makna Sumpah Pocong}

Berdasarkan tanda-tanda yang terdapat dalam pelaksanaan sumpah pocong, terdapat kesan makna bahwa sumpah pocong sebagai suatu cara menyelesaikan suatu permasalahan dengan meminta keputusan untuk membuktikan suatu kebenaran dengan melakukan sumpah kepada Allah SWT. Terdapat beberapa pendapat mengenai sumpah pocong, menurut Intisari (1996 dalam Kinasih, 2013, p. 2), sumpah pocong berarti pernyataan tentang janji yang dilakukan oleh penganut agama Islam, dengan cara dibalut seluruh tubuh dengan kain kafan seperti orang meninggal. Menurut wawancara dengan Informan 1, beliau berpendapat bahwa sumpah pocong pada dasarnya adalah tradisi/ budaya masyarakat yang merupakan pencampuran ritual Islam dan adat lokal yang dijalankan. Hal ini dapat terlihat dari rentetan proses dalam ritual sumpah pocong, yang mana pelaksanaan sumpah pocong diyakini tidak menyimpang dari ajaran agama Islam. Hal tersebut dapat dilihat dari setiap proses rentetan pelaksanaan sumpah. Seperti halnya yang pertama adalah berwudhu, kemudian membaca kalimat syahadat, dan bersumpah atas nama Allah, serta mengucapkan kalimat syahadat. Selain itu, tempat pelaksanaan sumpah pun dilaksanakan di Masjid Madegan, masjid yang sangat disakralkan dan dipercaya masyarakat memiliki kekuatan gaib yang dapat menambah kesakralan pada sumpah yang diucapkan. Sedangkan budaya yang dijalankan tergambar dari tanda-tanda yang digunakan seperti menyembelih ayam, mengelilingi pohon sawo, maupun kepercayaan akan kesakralan tongkat. Hal tersebut tidak lepas dari keyakinan dan kepercayaan masyarakat dan terus dilanggengkan hingga saat ini.

Senada dengan yang diungkapkan oleh Informan 2 yang mengatakan bahwa sumpah pocong merupakan suatu budaya masyarakat Madura yang digunakan sebagai cara terakhir untuk menyelesaikan masalah dan membersihkan nama baik atas tuduhan dari perseorangan. Beliau menambahkan bahwa sumpah pocong menurutnya sangat kental sekali dengan Islam jika dilihat dari proses pelaksanaannya yang dimulai dengan mengucap sumpah atas nama Allah, membaca dua kalimat syahadat, dan seterusnya. 
Namun berbeda halnya dengan yang diungkapkan oleh Informan 3 yang berpendapat bahwa sumpah pocong tidak terdapat dalam ajaran Islam. Hanya saja, memang dalam tata caranya mereka disumpah atas nama Allah. Sumpah pocong hanya berasaskan tuduhan yang belum jelas kebenarannya sehingga sumpah pocong diambil sebagai langkah untuk menyelesaikan permasalahan tersebut. Namun beliau juga mengatakan bahwa sumpah pocong merupakan suatu tradisi/budaya yang memang sudah ada dan dijalankan sejak dahulu.

Sehingga dapat dimaknai bahwa sumpah pocong merupakan suatu tradisi/budaya pada masyarakat Madura yang masih dijalankan dan diyakini. Namun pendapat mengenai makna dari sumpah pocong masih menjadi kontroversi dan terdapat berbagai pendapat juga pandangan yang berbeda mengenai sumpah pocong. Meski demikian, sumpah pocong masih tetap dilakukan oleh masyarakat hingga saat ini.

\section{KESIMPULAN}

Berdasarkan uraian di atas, dapat disimpulkan bahwa tanda-tanda yang ditemukan dalam pelaksanaan sumpah pocong antara lain bersumpah atas nama Allah, membaca kalimat syahadat, berwudhu, Masjid Madegan, ayam putih, pohon sawo, dan tongkat. Setiap hal tersusun atas berbagai tanda-tanda yang saling bekerja sama untuk menyampaikan suatu pesan tertentu. Sebagaimana pula dengan ritual atau tradisi yang masih dilakukan oleh beberapa orang untuk membuktikan suatu kebenaran melalui sumpah pocong. Dalam tradisi sumpah pocong, pesan-pesan tersebut dapat diidentifikasi melalui tanda-tanda yang muncul dalam ritual sumpah pocong, sebagaimana yang terdapat dalam setiap tata cara yang dilakukan. Meski demikian, dalam pemaknaan terhadap sumpah pocong, masyarakat memiliki pendapat yang berbeda-beda dan pandangan mereka masing-masing dalam memaknai sumpah pocong tersebut.

\section{DAFTAR PUSTAKA}

Anwar. (2008). KONSEP MUBAHALAH DAN PRAKTIK SUMPAH POCONG DI KABUPATEN SUMENEP-MADURA. Universitas Islam Negeri Sunan Kalijaga Yogyakarta.

Danial, E. (2009). Metode Penulisan Karya Ilmiah. Laboratorium Pendidikan Kewarnegaraan.

Halid, R. (2019). Analisis Semiotika Ferdinand de Saussure pada Novel Manjali dan Cakrabirawa Karya Ayu Utami. Skripsi. Universitas Muhammadiyah Makassar.

Hidayanto, F. (1993). Nilai Filosofis Kafarat Sumpah dalam Syari'at Islam.

Hosnanijatun. (2004). Babad Sampang. Dewan Perwakilan Daerah Kabupaten Sampang.

Intisari. (1996). Sumpah Pocong Menghindari Sumpah Bohong (Vol. 41).

Jamal, M. (2011). Konsep Al-Islam Dalam Al-Qur'an. Jurnal Al-Ulum, 11(2).

Kinasih, S. E. (2013). Sumpah Pocong: Upaya Penyelesaian Sengketa Masyarakat Madura (Studi Kasus di Masjid Madegan Desa Polagan, Sampang Madura. Jurnal Biokultur, II(1).

Koentjaraningrat. (1997). Metode Penelitian Masyarakat. PT. Pustaka Utama. Lexy, J., \& Moleong. (2007). Metodologi Penelitian Kualitatif. Remaja Rosdakarya. 


\section{Lakon: Jurnal Kajian Sastra dan Budaya Volume 10. No. 2, November 2021}

Nopiyanti, Y. (2020). Percaya Gak Percaya Ini Makna Sumpah Pocong.

Poerwandari, E., \& Kristi. (2005). Pendekatan Kualitatif dalam Penelitian Psikologi. Lembaga Pengembangan Sarana Pengukuran dan Pendidikan Psikologi Fakultas Psikologi UI.

Riyanto, D. E. (2003). The Problems of Concepts Between Islamic and English Terminology: The Case of Ritual Places and Activities. MOZAIK, 1(2).

Safri, S. H. (1993). Managemen Masjid: Suatu Pendekatan Teoritis dan Organisatoris. Dana Bakti Wakaf.

Saussure, F. de. (1996). Course in General Linguistics (Edited by Charles Bally and Albert Sechehaye Translated by Wade Baskin) (W. Baskin) (trans.)). McGrawHill Book Company.

Shiddiqi, A. H. (1987). Studies in Islamic History: Terjemahan: HMJ Irawan. AlMa'rif.

Subandi, M. (2007). Scholars in The Islamic Golden Ages in Revealing Scientific Information in the Qur'an. Dialektika Budaya Journal of Islamic Culture, History and Language, XIV(2).

Sugiyono. (2013). Metode Penelitian Pendidikan. Alfabeta.

Syafieh, \& Nurbaiti. (2018). Potret Karakteristik Kepemimpinan Perempuan (Analisis Semiotika Surat Al-Naml: 23-44. Jurnal At-Tibyan Jurnal Ilmu Alquran Dan Tafsir, 3(1), 52.

Syakirin. (2018). Peran Masjid dalam Mempersatukan Umat Islam. Al-Balagh Jurnal Dakwah Dan Komunikasi, 3(1, Hal), 127-148.

Usman, H., \& Setiady, A. (2017). Metodology Penelitian Sosial. PT. Bumi Aksara.

Wayadi, S. (2009). Hadis Tarbawi Pesan-pesan Nabi SAW Tentang Pendidikan. PT. Pustaka Firdaus. 